Tropical Journal of Pharmaceutical Research January 2016; 15 (1): 133-140

ISSN: $1596-5996$ (print); 1596-9827 (electronic) (c) Pharmacotherapy Group, Faculty of Pharmacy, University of Benin, Benin City, 300001 Nigeria.

All rights reserved.

Available online at http://www.tjpr.org

Original Research Article

http://dx.doi.org/10.4314/tjpr.v15i1.19

\title{
Evaluation of Antioxidant and Antifungal Activities of Polyphenol-rich Extracts of Dried Pulp of Garcinia pedunculata Roxb. and Garcinia morella Gaertn. (Clusiaceae)
}

\author{
Rahul Sarma, Minakshi Das, Tiluttama Mudoi, Kaustav Kalyan Sharma, Jibon \\ Kotoky and Rajlakshmi Devi*
}

Life Sciences Division, Institute of Advanced Study in Science and Technology (IASST) Vigyan Path, Paschim Boragaon, Garchuk, Guwahati-781035, Assam, India

${ }^{\star}$ For correspondence: Email: rajiasst@gmail.com; Tel/Fax: 0361-2279939

Received: 1 June 2015

Revised accepted: 11 December 2015

\begin{abstract}
Purpose: To evaluate the antioxidant and antifungal activities of polyphenol-rich extracts of the dried fruit pulp of Garcinia pedunculata (GP) and Garcinia morella (GM) to determine their traditional claims of therapeutic activity against certain diseases.

Methods: Analysis of total phenolic (TP) and flavonoid (TF) contents of the extracts were performed by Folin-Ciocalteau and Arvouet-Grand methods. The antioxidant activity of the extracts was determined by 1,1-diphenyl-2-picrylhydrazyl (DPPH), hydrogen peroxide $\left(\mathrm{H}_{2} \mathrm{O}_{2}\right)$ free radical scavenging activity, reducing power and in vitro lipid peroxidation (LPO). Antifungal activity was evaluated by agar-well diffusion method while mineral content was evaluated by atomic absorption spectrophotometry (AAS). Results: Significant amounts of TP (5.87 \pm 0.06 and $5.46 \pm 0.02 \mathrm{mg}$ catechin eqivalents/g) and TF $(5.61 \pm 0.16$ and $3.69 \pm 0.04 \mathrm{mg}$ quercetin equivalents $/ \mathrm{g}$ ) were found in the cold water $(\mathrm{CW})$ extracts of GP and GM, respectively, along with $D P P H$ free radical scavenging activity $(50 \%$ inhibitory concentration $\left(I C_{50}\right)=3.53 \pm 0.04$ and $\left.1 \pm 0.03 \mu \mathrm{g} / \mathrm{mL}\right)$ and $\mathrm{H}_{2} \mathrm{O}_{2}$-radical scavenging activity $\left(I C_{50}=1.4 \pm\right.$ 0.02 and $1.44 \pm 0.01 \mu \mathrm{g} / \mathrm{mL})$. Results indicated that the CW extracts of GP and GM were potent reducing agent than the HW extracts. CW extract of both species prevented in vitro $L P O\left(I C_{50}=42 \pm\right.$ 0.01 and $30.36 \pm 0.03 \mu \mathrm{g} / \mathrm{mL}$ ) significantly. The antifungal activity of GP and GM extracts against some human dermatophytes was high. High concentrations of $K$ and Fe were found in the extracts.

Conclusion: GP and GM extracts have great potential as a source for useful antioxidant and antifungal agents.
\end{abstract}

Keywords: Antioxidant, Phenolic, Flavonoid, Lipid peroxidation, Antifungal, Dermatophytes

Tropical Journal of Pharmaceutical Research is indexed by Science Citation Index (SciSearch), Scopus, International Pharmaceutical Abstract, Chemical Abstracts, Embase, Index Copernicus, EBSCO, African Index Medicus, JournalSeek, Journal Citation Reports/Science Edition, Directory of Open Access Journals (DOAJ), African Journal Online, Bioline International, Open-J-Gate and Pharmacy Abstracts

\section{INTRODUCTION}

Reactive oxygen species (ROS) such as superoxide anion $\left(\mathrm{O}^{-2}\right)$, perhydroxy radical $\left(\mathrm{HOO}^{-}\right.$ ), hydroxyl radical $\left(\mathrm{HO}^{-}\right)$and nitric oxide (NO) radical are generated during the process of cellular oxidation. These electrically charged radicals are highly unstable, reactive in nature and easily attack proteins, nucleic acid, mitochondria and enzymes in biological systems resulting damage in the cell. High levels of reactive free radicals and oxygen species create oxidative stress, which leads to detrimental effects, including lipid peroxidation (LPO) of 
cellular membranes, alteration of lipid-protein interaction, enzyme inactivation, DNA breakage, and eventually the promotion of mutations that initiate tumor progression [1,2].

Oxidative damage caused by free radicals and reactive oxygen species contribute to more than one hundred disorders in humans including atherosclerosis, arthritis, ischemia and reperfusion injury of many tissues, central nervous system injury, gastritis, diabetes and cancer $[3,6]$. Antioxidant plays an important role in protecting health from free radicals and reactive oxygen species. It is therefore important to evaluate the consumption of those fruits and vegetables which have been traditionally claimed for having therapeutic values.

GP and GM (family: Clusiaceae) are two popular indigenous fruits of NE region of India locally known as Bor thekera and Kuji thekera respectively. The mature fruit is eaten cooked or raw; generally it is mixed with other vegetables, especially with pulses. Dried pulp of these fruits is used as an antiscorbutic, astringent, cooling, cardiotonic, emollient, antidiarrhoeic, antidysentric, indyspepsia and in flatulence [7]. A field survey was carried out in different parts of Assam to collect the views of different people about the use of GP and GM fruits whereby maximum people claimed the use of dried pulp of the fruit is having therapeutic value than the consumption of raw fruits [8]. In this regard, the dried pulps of the fruit tested on cholesterol fed mice in our laboratory and it showed the hypolipidemic and anti-atherosclorotic effect [9].

There are hardly any reports available on antioxidant and antifungal activity of the GP and GM fruits of NE region of India. So, this study was designed to determine the antioxidant and antifungal activity of polyphenolic enriched extracts of GP and GM fruits.

\section{EXPERIMENTAL}

\section{Plant material}

The fruits GP and GM were collected from local markets of Assam, India in the month of April 2013 with authentication by the Botanist of Gauhati University, Guwahati, Assam and a voucher specimens (IASST/LSD/PM-11 and IASST/LSD/PM-12) were deposited at the medicinal and aromatic plant section, Life Sciences Department, Institute of Advanced Study in Science and Technology (IASST), Assam, India. The fruits were cut into small pieces, sundried for 10-15 days and kept at room temperature for further analysis.

\section{Preparation of cold and hot water extracts}

Cold water (CW) extracts of dried pulp of GP and GM were prepared by soaking $5 \mathrm{~g}$ of dried pulp in $100 \mathrm{~mL}$ drinking water. The mixture was stirred vigorously and allowed to stand for $24 \mathrm{~h}$ at room temperature. Thereafter, it was filtered by Whatman filter paper and stored at $4{ }^{\circ} \mathrm{C}$ for further use. For hot water (HW) extraction, $5 \mathrm{~g}$ of dried pulp each of GP and GM were kept in 100 $\mathrm{mL}$ of drinking water and the samples were boiled for $30 \mathrm{~min}$ and added into a conical flask and agitated on a rotary shaker for $48 \mathrm{~h}$. Then it was filtered by Whatman filter paper (diameter $125 \mathrm{~mm}$ ) and filtrate was stored at $4{ }^{\circ} \mathrm{C}$ for analysis of different parameters.

\section{Determination of total phenolic content (TPC)}

TPC of dried pulp extract of GP and GM was determined by Folin-Ciocalteu method with slight modification [10] Briefly, $0.5 \mathrm{~mL}$ of extract was mixed with Folin-Ciocalteu reagent $(2.5 \mathrm{~mL}$, diluted 10 times) and incubated for $2 \mathrm{~min}$ at room temperature followed by addition of sodium carbonate solution ( $2 \mathrm{~mL}, 7.5 \% \mathrm{w} / \mathrm{v})$. The mixture was then allowed to stand for $30 \mathrm{~min}$ at room temperature and absorbance was measured at $765 \mathrm{~nm}$. TPC was calculated as a catechin equivalence from the calibration curve of catechin standard solutions and expressed as $\mathrm{mg}$ catechin/g dried pulp of the sample.

\section{Evaluation of total flavonoid content (TFC)}

TFC was estimated according to the Dowd method as adapted by Arvouet-Grand et al [11]. Briefly, $2 \mathrm{~mL}$ of extract was mixed with $2 \mathrm{~mL}$ of aluminiumtrichloride $\left(\mathrm{AlCl}_{3}\right)$ in methanol $(2 \%)$. The absorbance was read at $415 \mathrm{~nm}$ after 10 min. Quercetin was used as reference compound and the results were expressed as $\mathrm{mg}$ of quercetin equivalence (QE)/g of dried pulp of fruit.

\section{Evaluation of 2, 2-diphenyl-1-picrylhydrazyl (DPPH) radical scavenging activity}

The free radical scavenging ability of the extracts against DPPH free radical was evaluated as described by DPPH method [12]. The solution of DPPH in methanol $\left(6 \times 10^{-5} \mathrm{M}\right)$ was prepared just before UV measurements. Samples were added to DPPH solution in 1:1 ratio followed by vortexing. The reaction was allowed to take place in the dark at room temperature. The absorbance at $515 \mathrm{~nm}$ was measured at different time 
intervals. Ascorbic acid served as a standard. $I_{50}$ value (the concentration required to scavenge $50 \%$ of the free radical) was estimated from a plot of \% inhibition against concentrations of the sample solutions. Scavenging activity (S) was calculated as Eq 1.

$S(\%)=\{(A c-A s) / A c\} 100$.

where Ac and As are the absorbance of control and sample, respectively.

\section{Determination of hydrogen peroxide $\left(\mathrm{H}_{2} \mathrm{O}_{2}\right)$ scavenging activity}

The scavenging assay for $\mathrm{H}_{2} \mathrm{O}_{2}$ was performed by a standard method [13]. A $43 \mathrm{mM}$ solution of $\mathrm{H}_{2} \mathrm{O}_{2}$ was prepared in $0.1 \mathrm{M}$ phosphate buffer solution ( $\mathrm{pH}$ 7.4). Samples (1 mL) were mixed with $43 \mathrm{mM} \mathrm{H}_{2} \mathrm{O}_{2}$ solution $(0.6 \mathrm{~mL})$. After $10 \mathrm{~min}$, the reaction mixture absorbance was determined at $230 \mathrm{~nm}$. The phosphate buffer without hydrogen peroxide was used as a blank. Ascorbic acid was used as a reference compound. $\mathrm{H}_{2} \mathrm{O}_{2}$-scavenging activity $(\mathrm{H})$ of calculated as in Eq 2.

$H(\%)=\{(A c-A s) / A c\} 100$

where Ac and As are the absorbance of control and sample, respectively.

\section{Assessment of reducing power activity}

Reducing power of samples was determined by ferric reducing power assay [14]. Briefly, $2.5 \mathrm{~mL}$ of $0.2 \mathrm{M}$ phosphate buffer $(\mathrm{pH} 6.6)$ and $2.5 \mathrm{~mL}$ of $1 \%$ potassium ferricyanide were added to $1 \mathrm{~mL}$ sample solution and mixed gently. The mixtures were incubated at $50{ }^{\circ} \mathrm{C}$ in a water bath for 20 min. Reaction was stopped by adding $2.5 \mathrm{~mL}$ of $10 \%$ trichloroacetic acid (TCA) and the mixtures were centrifuged at $4000 \mathrm{rpm}$ for $10 \mathrm{~min}$. From the top layer, $2.5 \mathrm{~mL}$ was transferred into tubes containing $2.5 \mathrm{~mL}$ distilled water and $0.5 \mathrm{~mL}$ of $0.1 \%$ ferric chloride $\left(\mathrm{FeCl}_{3} \cdot 6 \mathrm{H}_{2} \mathrm{O}\right)$. The resulting solutions were mixed well and after $5 \mathrm{~min}$ the absorbance was measured at $700 \mathrm{~nm}$ against blanks.

\section{In vitro lipid peroxidation (LPO)}

LPO induced by $\mathrm{Fe}^{2+}$-ascorbate system in rat liver homogenate [15], was estimated as thiobarbituric acid reacting substances (TBARS) [16]. The reaction mixture contained rat liver homogenate $0.25 \mathrm{~mL}(10 \% \mathrm{w} / \mathrm{v}$ in $0.05 \mathrm{M}$ phosphate buffer, $\mathrm{pH} 7.4), 0.1 \mathrm{~mL}$ tris- $\mathrm{HCl}$ buffer (150 mM, pH 7.2), $0.05 \mathrm{~mL}$ ascorbic acid (0.1 $\mathrm{mM}), 0.05 \mathrm{~mL} \mathrm{FeSO}_{4} .7 \mathrm{H}_{2} \mathrm{O}(4 \mathrm{mM})$ and $0.05 \mathrm{~mL}$ of fruit extract. The mixture was incubated at 37 ${ }^{\circ} \mathrm{C}$ for $1 \mathrm{~h}$ and then $1.5 \mathrm{~mL}$ 2-thiobarbituric acid (TBA, $0.8 \% \mathrm{w} / \mathrm{v}$ ), $1.5 \mathrm{~mL}$ acetic acid $(20 \%)$ and $0.2 \mathrm{~mL}$ sodiumdodecyl sulfate (SDS, $8.1 \% \mathrm{w} / \mathrm{v}$ ) were added to the reaction mixture. The mixture was made up to $4.0 \mathrm{~mL}$ with distilled water and heated at $95^{\circ} \mathrm{C}$ for $60 \mathrm{~min}$. After cooling with tap water, $1.0 \mathrm{~mL}$ distilled water and $5.0 \mathrm{~mL}$ of a mixture of $\mathrm{n}$-butanol and pyridine $(15: 1, \mathrm{v} / \mathrm{v})$ were added. The mixture was shaken vigorously and centrifuged at $5000 \mathrm{rpm}$ for $10 \mathrm{~min}$. After centrifugation, the optical density of the butanol layer was measured at $532 \mathrm{~nm}$.

\section{Assay for antifungal activity}

The screening of antifungal activity of the extracts was determined by employing agar well diffusion method $[17,18]$.

\section{Preparation of working stock}

Fungal strains were procured from Institute of Microbial Technology (IMTECH), Chandigarh160036 (India). The organisms used were Trichophyton rubrum (MTCC 8477), Microsporum gypseum (MTCC 8469) and Microsporum fulvum (MTCC 8478). The procured samples were subcultured and maintained in Sabouraud Dextrose Agar (HIMEDIA) slants at 4 ${ }^{\circ} \mathrm{C}$.

Agar-well diffusion method was employed for testing antifungal activity of the extracts of garcinia fruit. With a sterile cotton swab, $0.2 \mathrm{~mL}$ of fungal inoculum was spread evenly on the surface of the petri plate containing solidified SDA. Well of $6 \mathrm{~mm}$ diameter was made in the center of the agar plate with a sterile cork borer. The well was then filled with the respective extracts $(0.3 \mathrm{~mL})$ and allowed to diffuse at room temperature for $2 \mathrm{~h}$. A control set was maintained with DMSO. Clotrimazole was used as a reference standard. The plates were then incubated at $28 \pm 2^{\circ} \mathrm{C}$ for $7-21$ days depending on the growth rate of the test pathogens. The experiment was replicated thrice and the average results were recorded.

\section{Mineral content analysis}

Mineral content was analyzed with Atomic Absorption Spectrophotometer, SIMADZU AAC7000 analyzer. Dried pulp of GP and GM (100 $\mathrm{mg}$ ) was digested with $3 \mathrm{~mL}$ concentrated nitric acid $(65 \%)$ and $0.25 \mathrm{~mL}$ hydrogen peroxide until a transparent solution was obtained. Finally after digestion the volume is made up to $30 \mathrm{~mL}$ with distilled water. The instrument was calibrated with known standards and samples analyzed at 
corresponding wavelengths. $\mathrm{Na}$ and $\mathrm{K}$ were determined by Flame photometer, ELICO CL378.

\section{Statistical analysis}

All assays were carried out in triplicate and the results expressed as mean \pm SEM. Statistical analysis was carried out using Statistical Package for the Social Sciences (SPSS), version 16.0 , and data analyzed using t-test, and $p<$ 0.05 was considered statistically significant.

\section{RESULTS}

\section{TPC, TFC and antioxidant activities of GP and GM.}

TPC of CW and HW extracts of GP was $5.87 \pm$ 0.06 and $4.45 \pm 0.02 \mathrm{mg}$ catechin equivalents $/ \mathrm{gm}$ dry weight and in GM it was $5.46 \pm 0.02$ and 3.8 $\pm 0.3 \mathrm{mg}$ catechin equivalents/gm dry weight respectively. It was thus revealed that the TPC in $\mathrm{CW}$ extracts was higher than that of HW extracts. TFC of CW and HW extracts of GP was found to be $5.61 \pm 0.16$ and $5.48 \pm 0.05 \mathrm{mg}$ quercetin equivalents/gm dry weight and in GM $3.69 \pm 0.04$ and $1.43 \mathrm{mg}$ quercetin equivalents/gm dry weight respectively. TFC in both the extracts of GP were almost similar.

Similarly, in the case of DPPH, the $\mathrm{IC}_{50}$ values of the $\mathrm{CW}$ extracts were much lower $(3.53 \pm 0.04$ and $1 \pm 0.03 \mu \mathrm{g} / \mathrm{mL}$ ) than than the standard ascorbic acid $(5.56 \pm 0.03 \mu \mathrm{g} / \mathrm{mL})$ and it indicated that the GP and GM contained high antioxidant activity. Lower $\mathrm{IC}_{50}$ values indicated greater scavenging power. From the present results, it may be postulated that $\mathrm{CW}$ and $\mathrm{HW}$ extracts of GP and GM reduces the radical to corresponding hydrazine when it reacts with hydrogen donors in antioxidant principles. In case of $\mathrm{H}_{2} \mathrm{O}_{2}$, the $\mathrm{IC}_{50}$ values of $\mathrm{CW}$ extracts of GP and GM found to be $1.4 \pm 0.02$ and $1.44 \pm$
$0.01 \mu \mathrm{g} / \mathrm{mL}$ respectively quite comparable with ascorbic acid $(1 \pm 0.03 \mu \mathrm{g} / \mathrm{mL})$ whereas higher values of $\mathrm{IC}_{50}$ values in case of $\mathrm{HW}$ extracts of both GP and GM indicates that some compounds destroyed during the boiling condition. Again CW and HW extracts of GM potentially inhibited the in vitro lipid peroxidation with an $\mathrm{IC}_{50}$ value of $30.36 \pm 0.03$ and $34.6 \pm 0.03 \mu \mathrm{g} / \mathrm{mL}$ against ascorbic acid $18 \pm 0.03 \mu \mathrm{g} / \mathrm{mL}$ (Table 1).

The reducing power of $\mathrm{CW}$ and $\mathrm{HW}$ extracts of GP and GM increased with increasing concentration. The antioxidant activities reported were concomitant with the development of reducing power. All the concentration of water extract showed significant activities when compared to standard ascorbic acid. The reducing power of the CW extract of GP and GM were higher than that of the HW extracts (Fig 1).

\section{Antifungal activity}

At $20 \mathrm{mg} / \mathrm{mL}$ concentration, CW extract of GP and $\mathrm{GM}$ showed $19 \mathrm{~mm}$ and $15 \mathrm{~mm}$ zone diameter against Mycrosporum falvum (MF). At the same concentration, CW extract of GP and GM showed 13, 14 and 21, $22 \mathrm{~mm}$ zone diameter against Mycrosporum gypseum (MG) and Trichophyton rubrum (TR) respectively. But HW extract of GP and GM showed less activity. For this study a particular concentration (20 $\mathrm{mg} / \mathrm{mL}$ ) was considered, at which these fruits showed antifungal activity against some skin pathogenic fungi (Table 2).

\section{Mineral content of GP and GM}

Table 3 showed that $\mathrm{K}, \mathrm{Na}, \mathrm{Fe}, \mathrm{Cu}, \mathrm{Mn}$ and $\mathrm{Zn}$ content of the samples were high in GP and GM but $\mathrm{Ni}, \mathrm{Co}, \mathrm{Pb}$ and Se were not detected. GP and GM were rich sources of $\mathrm{Fe}(2.98 \pm 0.14$ and $3.10 \pm 0.11 \mathrm{mg} / 100 \mathrm{~g}$ pulp).

Table 1: In vitro antioxidant activities, total phenolic and flavonoid content of GP and GM

\begin{tabular}{|c|c|c|c|c|c|}
\hline \multirow[b]{2}{*}{ Test sample } & \multicolumn{3}{|c|}{$\mathrm{IC}_{50}(\mu \mathrm{g} / \mathrm{mL})$} & \multirow{2}{*}{$\begin{array}{c}\text { TPC } \\
(\mathrm{mg} \mathrm{catechin} / \mathrm{g})\end{array}$} & \multirow{2}{*}{$\begin{array}{c}\text { TFC } \\
(\mathrm{mg} \text { quercetin } / \mathrm{g})\end{array}$} \\
\hline & DPPH & $\mathrm{H}_{2} \mathrm{O}_{2}$ & $\begin{array}{c}\text { Lipid } \\
\text { peroxidation }\end{array}$ & & \\
\hline $\mathrm{GP}(\mathrm{CW})$ & $3.53 \pm 0.04^{a}$ & $1.4 \pm 0.02^{b}$ & $42 \pm 0.01^{a}$ & $5.87 \pm 0.06^{a}$ & $5.61 \pm 0.16^{\mathrm{a}}$ \\
\hline $\mathrm{GP}(\mathrm{HW})$ & $5.28 \pm 0.03^{a}$ & $2 \pm 0.03^{a}$ & $59 \pm 0.04^{a}$ & $4.45 \pm 0.02^{\mathrm{a}}$ & $5.48 \pm 0.05^{a}$ \\
\hline GM (CW) & $1 \pm 0.03^{b}$ & $1.44 \pm 0.01^{b}$ & $30.36 \pm 0.03^{a}$ & $5.46 \pm 0.02^{\mathrm{a}}$ & $3.69 \pm 0.04^{a}$ \\
\hline GM (HW) & $1.84 \pm 0.01^{b}$ & $2.39 \pm 0.04^{\mathrm{a}}$ & $34.6 \pm 0.03^{\mathrm{a}}$ & $3.8 \pm 0.3^{b}$ & $1.43 \pm 0.02^{b}$ \\
\hline Ascorbic acid & $5.56 \pm 0.03^{a}$ & $1 \pm 0.03^{b}$ & $18 \pm 0.03^{b}$ & - & - \\
\hline
\end{tabular}

The results were the average of three determination \pm SEM in the same column with the different letters are significantly different $(p<0.05)$ 


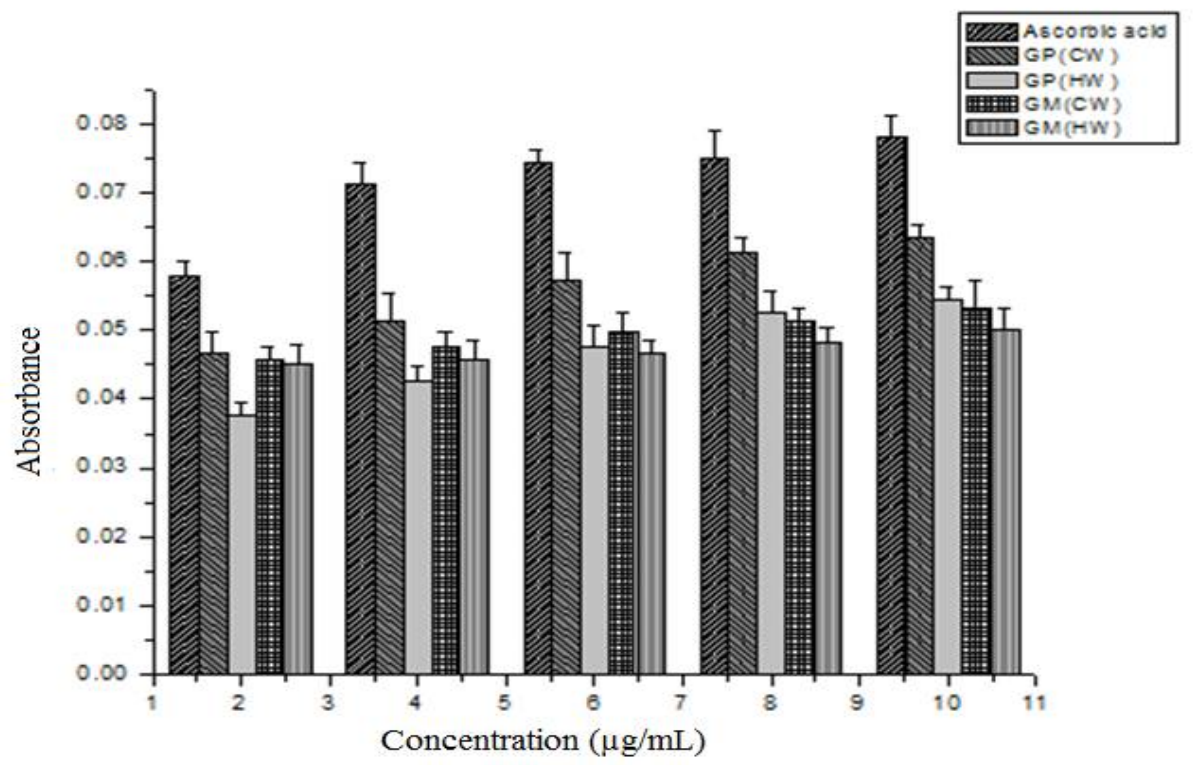

Figure 1: Reducing power of CW and HW extract of GP and GM fruits compared with Ascorbic acid. Data are mean $\pm \operatorname{SEM}(n=3)$

Table 2: Inhibition zone diameter of GP and GM at different concentrations

\begin{tabular}{|c|c|c|c|c|c|}
\hline \multirow[t]{2}{*}{ Sample } & \multirow[t]{2}{*}{ Extract } & \multirow[t]{2}{*}{ Conc. (mg/mL) } & \multicolumn{3}{|c|}{ Inhibition Zone (mm) } \\
\hline & & & T. rubrum & M. gypseum & M. fulvum \\
\hline & & 5 & $\overline{(-)}$ & $(-)$ & $(-)$ \\
\hline & CW & 10 & 12 & 11 & 13 \\
\hline & & 20 & 21 & 13 & 19 \\
\hline \multicolumn{6}{|l|}{ GP } \\
\hline & 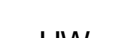 & 5 & $(-)$ & $(-)$ & $(-)$ \\
\hline & $H V$ & $\begin{array}{l}10 \\
20\end{array}$ & $\begin{array}{l}(-) \\
11\end{array}$ & $(-)$ & $(-)$ \\
\hline & & 5 & $(-)$ & $\frac{1}{(-)}$ & $\frac{(-)}{7}$ \\
\hline & $\mathrm{CW}$ & 10 & 13 & 10 & 12 \\
\hline & & 20 & 22 & 14 & 15 \\
\hline \multicolumn{6}{|l|}{ GM } \\
\hline & & 5 & $(-)$ & $(-)$ & $(-)$ \\
\hline & HW & 10 & $(-)$ & $(-)$ & $(-)$ \\
\hline & & 20 & $(-)$ & $(-)$ & $(-)$ \\
\hline Clotrimazole & & 0.5 & 22 & 27 & 25 \\
\hline
\end{tabular}

Table 3: Mineral composition of GP and GM

\begin{tabular}{|c|c|c|}
\hline \multirow{2}{*}{$\begin{array}{l}\text { Mineral } \\
\text { (mg/100g pulp) }\end{array}$} & \multicolumn{2}{|c|}{ Content(mean $\pm S D)$} \\
\hline & GP & GM \\
\hline$\overline{\mathrm{K}}$ & $63.48 \pm 0.3$ & $67.68 \pm 0.3$ \\
\hline $\mathrm{Na}$ & $1.0 \pm 0.07$ & $1.00 \pm 0.01$ \\
\hline $\mathrm{Fe}$ & $2.98 \pm 0.14$ & $3.10 \pm 0.11$ \\
\hline $\mathrm{Cu}$ & $0.39 \pm 0.01$ & $0.30 \pm 0.014$ \\
\hline $\mathrm{Mn}$ & $0.23 \pm 0.004$ & $0.14 \pm 0.003$ \\
\hline $\mathrm{Zn}$ & $0.69 \pm 0.30$ & $0.78 \pm 0.001$ \\
\hline $\mathrm{Ni}$ & ND & ND \\
\hline Co & ND & ND \\
\hline $\mathrm{Cd}$ & $0.002 \pm 0.0001$ & $0.0020 \pm 0.0003$ \\
\hline $\mathrm{Pb}$ & ND & ND \\
\hline $\mathrm{Cr}$ & $0.03 \pm 0.002$ & $0.05 \pm 0.002$ \\
\hline $\mathrm{Se}$ & ND & ND \\
\hline
\end{tabular}




\section{DISCUSSION}

The emphasis on plant antioxidant has been increasing substantially in the recent times for the apprehension of some side effects of commercial antioxidants. The medicinal plants have different kinds of bioactive compounds, which have capabilities for termination of free radical chain reaction.

Phenolics and flavonoids are two main groups of polyphenols and both of these compounds are reported in fruits and vegetables. These two contents in fruits and vegetables can be influenced by species variety, environmental and growing conditions, maturity stages and harvesting factor [19-21]. Present study focused on the presence of phenolics and flavonoids in the dried pulp of GP and GM in CW and HW extracts of these two species separately. The study revealed that the TPC in the dried pulp of GP and GM fruit were found in higher amount in CW extracts than that of the HW extracts of both the fruits. Similarly, the CW extracts of GP and GM showed higher content of TFC. The present study clearly revealed that $\mathrm{CW}$ extracts are richer than HW extracts in TPC and TFC.

DPPH is a stable free radical, which was scavenged/neutralized by the extracts in a dosedependent manner exhibiting high antioxidant potential of the extracts. Compounds with high antioxidant potential having high reduction capability of DPPH molecules. $\mathrm{IC}_{50}$ (amount of antioxidant present in the sample necessary to decrease the initial concentration by $50 \%$ ) value was calculated to determine the strength of antioxidant potential of the extracts. The lower the $I_{50}$ value, the higher is the antioxidant activity. CW extracts of GP and GM showed the lowest $I_{50}$ value in comparison to that of standard drug ascorbic acid in case of DPPH free radical scavenging activity.

$\mathrm{H}_{2} \mathrm{O}_{2}$ can cross cell membrane rapidly and produce hydroxyl radical, which can lead damage to the cell [22]. $\mathrm{H}_{2} \mathrm{O}_{2}$ probably reacts with $\mathrm{Fe}^{2+}$ and possibly $\mathrm{Cu}^{2+}$ ions to form hydroxyl radical, which may be the origin of many of its toxic effects [23]. So, it is necessary for cells to control the accumulation of $\mathrm{H}_{2} \mathrm{O}_{2}$ in the cells. In the present study, the $\mathrm{CW}$ extracts of both GP and $\mathrm{GM}$ scavenged the $\mathrm{H}_{2} \mathrm{O}_{2}$ radical very effectively and it was almost similar to that of the standard ascorbic acid. (Table 1). It is apparent from that the $\mathrm{IC}_{50}$ values of $\mathrm{CW}$ extracts of $\mathrm{GP}$ and $\mathrm{GM}$ against $\mathrm{H}_{2} \mathrm{O}_{2}$ free radical that $\mathrm{CW}$ extracts of both the species were much more effective which can be compared with the standard drug ascorbic acid.
The reducing capacity of a compound may serve as a significant indicator of its potential antioxidant activity [24]. The reducing power of the test sample always determined by the color changes of the test samples from yellow to green, due to the reduction of $\mathrm{Fe}^{3+} /$ ferricyanide complex to the ferrous form and $\mathrm{Fe}^{2+}$ can be monitored by the measurement of the absorbance (OD value) at $700 \mathrm{~nm}$ [25]. CW extract showed very good reducing power than that of HW extracts.

Initiation of LPO by ferrous sulphate takes place through ferryl-perferryl complex [26]. The peroxidation of membrane lipids initiated by oxygen radical's causes cardiovascular diseases and cancer [27]. This process may occur under enzymatic or non-enzymatic control. There has been an increasing interest in lipid peroxidation because formation of cytotoxic products such as MDA and 4-hydoxynonenal can influence cell function and the course of major human diseases [28]. In the present study, pink colour of MDATBA complex was detected at $532 \mathrm{~nm}$ and the inhibitory effect of $\mathrm{CW}$ and HW extracts of GP and GM on both ferric ion and ascorbic acid induced LPO on rat liver homogenate were calculated. The study showed that $I C_{50}$ value of CW extracts of GP and GM against in vitro LPO is considerably low (Table 1), indicating that the extract are having excellent antioxidant potentiality.

Ethno medicines hold a great promise as a source of easily available effective antifungal agents particularly in developing countries, including India. Indigenous system of traditional medicine reports a number of plants for their antifungal efficacy [29]. The GP and GM extracts of the plant used in this study were found to be effective against the human dermatophytes. Table 2 showed that CW extracts of GP and GM showed good antifungal activity.

Many antioxidant defenses depend on micronutrients. Some minerals are components of antioxidants enzymes: superoxide dismutase depends on $\mathrm{Mn}, \mathrm{Cu}$ and $\mathrm{Zn}$; catalase depends on $\mathrm{Fe}$, and glutathione peroxidase on $\mathrm{Se} \mathrm{[30].} \mathrm{Of}$ all minerals evaluated for GP and GM, K and $\mathrm{Fe}$ were detected in higher concentrations than other minerals. The ratio of $\mathrm{K}$ and $\mathrm{Na}$ plays an important role in maintaining the electrolyte balance of cells in the human body. $\mathrm{Fe}$ is an important part of hemoglobin for carrying oxygen to the body tissues. The availability of higher concentration of $\mathrm{Fe}$ in the samples indicates greater antioxidant properties. 


\section{CONCLUSION}

The results obtained in the present study indicate that CW extracts of GP and GM exhibit higher reducing power, free radical scavenging and antifungal activity than HW extracts. There is thus some justification for the use by local tribes of NE region India, of the CW infusion of dried pulp of GP and GM against oxidative stressrelated diseases. The findings of the present study suggest that GP and GM extracts are a potential source of natural antioxidant that may have great importance as therapeutic agents in preventing or slowing the progress of aging and oxidative stress related degenerative diseases.

\section{ACKNOWLEDGEMENT}

The authors acknowledge financial support from Department of Indian Council of Medical Research (ICMR), Government of India, New Delhi, India, for this work.

\section{REFERENCES}

1. Agarwal A, Saleh RA, Bedaiwy MA. Role of reactive oxygen species in the pathophysiology of human reproduction. Fertil. Steril. 2003; 79: 829-843.

2. Lefebvre PP, Malgrange $B$, Lallemend $F$, Staecker $H$, Moonen G, and Van De Water TR. Mechanisms of cell death in the injured auditory system: Otoprotective strategies. Audiol. Neurootol. 2002; 7: 165-170.

3. Pourmorad F, Hosseinimehr SJ, Shahabimajd $N$. Antioxidant activity, phenol and flavonoid contents of some selected Iranian medicinal plants. African J Biotech 2006; 5: 1142-1145.

4. Wong SP, Leong LP, Koh JHW. Antioxidant activities of aqueous extracts of selected plants. Food Chem 2006; 99: 775-783.

5. Su L, Yin JJ, Charles D, Zhou K, Moore J, Yu L. Total phenolic contents, chelating capacities, and radicalscavenging properties of black peppercorn, nutmeg, rosehip, cinnamon and oregano leaf. Food Chem 2007; 100: 990-997.

6. Tepe B, Eminagaoglu O, Akpulat HA, Aydin E. Antioxidant potentials and rosmarinic acid levels of the methanolic extracts of Salvia verticillata(L.) subsp. verticillata and $S$. verticillata(L.) subsp. Amasiaca(Freyn\&Bornm.) Bornm. Food Chem 2007; 100: 985-989.

7. Kagyung $R$, Gajurel $P R$, Rethy $P$, Singh $B$. Ethnomedicinal plants used for gastrointestinal diseases by Aditribes of Dehang-Debang Biosphere Reserve in Arunachal Pradesh. Indian J Trad Knowl 2010; 9: 496501.

8. Sarma R, Devi R. Ethnopharmacological survey of Garcinia pedunculata Roxb. Fruit in six different districts of Assam, India. Int J Pharma Sci Inv 2015; 4: 20-28.
9. Pator A, Kotoky J, Baruah DC, Mudoi T, Sharma KK, Devi D, Devi R. Hypolipidemic and antiatherosclerotic effect of dried pulp of Garcinia morella fruit in cholesterol fed mice.Asian J ExpBioSci 2011; 2: 237-245.

10. Folin $O$, Ciocalteu V. On tyrosine and tryptophan determination in proteins. J Biol Chem 1927; 27: 627650.

11. Arvouet-grand A, Vennat B,Pourrat $A$, Legret $P$. Standardization d'unextraitde propolis et identification desprincipaux constituants.J Pharm Belg 1994; 49: 462468.

12. Brand-williams W, Cuvelier ME, Berset C. Use of free radical method to evaluate antioxidant activity. Lebensmittel Wissenschaft and Technologie1995; 28 : 25-30.

13. Ruch RT, Cheng SJ, Klaunig JE. Spin trapping of superoxide and hydroxyl radicals. Methods in Enzy1984; 105: 198-209.

14. Oyaizu M. Antioxidaive activities of browning products of glucosamine fractionated by organic solvent and thinlayer chromatography. Nippon Shokuhin Kogyo Gakkaishi1988; 35: 771-775.

15. Bishayee S, Balasubramaniyam AS. Assay of lipid peroxide formation. Neurochem 1971; 18(6): 909-920.

16. Okhawa H, Oohishi N, Yagi K. Assay of lipid peroxidation in animal tissue by thiobarbituric acid reaction. Anal Biochem 1979; 95(2): 351-358.

17. Grammar A. Antibiotic sensitivity and assay test. In: Collins C.H, Lyne PM., Grange J.M., editors. Microbiological Methods. 6th ed. London: Bulterworths and Co. Ltd, 1976.

18. Motiejunaite $O$, Peciulyte D. Fungicidal properties of Pinussyl vestris $L$ for improvement of air quality. Medicina (Kaunas) 2004; 40(8): 787-793.

19. Marin A, Ferreres F, Tomas-Barberan FA, Gil MI. Characterization and quantification of antioxidant constituents of sweet pepper. J Agric Food Chem 2004; 52: 3861-3869.

20. Naczk M, Shahidi F. Phenolics in cereals, fruits and vegetables: Occurrence, extraction and analysis. J. Pharma Biomed Anal 2006; 41: 1523-1542.

21. Hogan S, Zhang L, Li J, Zoecklein B, Zhou K. Antioxidant properties and bioactive components of Norton (Vitis aestivalis) and Cabernet Franc (Vitis vinifera) wine grapes. LWT-Food Sci Tech 2009; 42: 1269-1274.

22. Halliwell, B. Reactive oxygen species in living systems: Source, biochemistry, and role in human disease. Am J. Medicine 1991; 91: 14-20.

23. Miller MJ, Sadowska-Krowicha H, Chotinaruemol $S$, Kakkis JL, Clark DA. Amelioration of chronic ileitis by nitric oxide synthase inhibition. J. Pharmacol. Exp. Ther. 1993; 264(1): 11-16.

24. Meir S, Kanner J, Akiri B, Philosoph-Hadas S. Determination and involvement of aqueous reducing compounds in oxidative defense systems of various senescing leaves. J. Agric. Food Chem 1995; 43: 18131819. 
25. Zou Y, Lu Y, Wei D. Antioxidant activity of a flavonoidrich extract of Hypericum perforatum L. in vitro Agric Food Chem 2004; 52: 5033-5039.

26. Gutteridge JM. Age pigments and free radicals fluorescent lipid complexes formed by iron and copper containing proteins. Biochim Biophys Acta 1985; 834: 144-148.

27. Atmani D, N Chaher, M Berboucha, $K$ Ayouni, $H$ Lounis, $H$ Boudaoud, N Debbache. Antioxidant capacity and phenol content of selected Algerian medicinal plants. Food Chem 2009; 112: 303-309.
28. Sevanian A, Ursini F. Lipid peroxidation in membranes and low density lipoproteins: similarities and differences. Free Radical Biol Med 2000; 29: 306-311.

29. Vinayakak S, Prashithkekunda TR, Raghavendra HL, Sandeep M. otari, Swarnalatha SP, Surabhi KS, Preethi HR. Antidermatophyte and Antioxidant potential of Remisatia vivipara. Int. J Drug Dev Res 2010; 2: 96-101.

30. Evans $P$, Halliwell B. Micronutrients: Oxidant/antioxidant status. British J Nutr 2001; 85: S67-S74. 